\title{
Multiculturalism and Political Integration in Modern Nation State
}

\author{
John Rex (University of Warwick, UK)
}

\begin{abstract}
Resum / Resumen
The article produce a general theory of multiculturalism and place within an overall conceptual framework the structures and processes of multiculturalism as a central question in the political concerns of European countries since 1945. The article ranged widely over a number of topics including nationalism and devolution in West Europe, South East Europe and the countries of the former Soviet Union and deal with the settlement of immigrant minorities. / L'article elabora una teoria general del multiculturalisme $i$ situa dins un marc conceptual les estructures i processos del multiculturalisme tractat com a una qüestió central de les polítiques dels països europeus des de 1945. Partint d'aquí l'article tracta diversos temes com el nacionalisme a Europa occidental, l'Europa del sud-est i els països de l'antiga Unió Soviètica focalitzant en el tema dels immigrants. / El artículo elabora una teoría general del multiculturalismo y sitúa dentro de un marco conceptual las estructuras y procesos del multiculturalismo tratado como una cuestión central de las políticas de los países europeos des de 1945. El articulo, asimismo, trata diversos temas como el nacionalismo en la Europa occidental, en la Europa del sureste y en los países de la antigua Unión Soviética centrándose en el tema de los inmigrantes.
\end{abstract}

\section{Key Words / Paraules clau / Palabras clave}

Immigrant minorities, identity, multiculturalism, Nationalism, Welfare State / Immigració, minories, identitat, multiculturalisme, nacionalisme, estat del benestar/Immigration, minories, identity, multiculturalism, nacionalism, estado del bienestar

1. The question of multiculturalism has been a central one in the political concerns of European countries since 1945. It covers a number of different issues however and which of them predominates has varied with differing political circumstances. It reflected concern about immigration and the ways in which immigrants might settle in Western Europe in the nineteen fifties and sixties. After the break-up of Communism in 1989 and the resurgence of ethnic nationalism in the East it centred around questions of devolution of power from central national governments to regionally based sub-national groups and the possibilities of power sharing at the centre. Thirdly it has had to deal with the growing numbers of political refugees and asylum seekers in Western Europe. Fourthly, and most recently, in the wake of terrorist attacks on America and the subsequent assertion of American power in the world at large it has been concerned with the dangers posed by unassimilated immigrant groups.

2. It is not the intention of this article to deal in detail with each of the structures and processes in all the different political situations to which reference will be made. Rather it seeks to place these situations within an overall conceptual framework and, in doing so, to produce a general theory of multiculturalism. 


\section{Multiculturalism in Popular Discourse}

3. There are few terms used more widely in popular discourse in the media and in politics than multiculturalism. Until recently it was discussed as a positive feature of national societies and cities. Politicians and even monarchs would say "We now live in a multicultural society" and cities would boast that they were now multicultural or, sometimes cosmopolitan These usages we may refer to as soft versions of multiculturalism

4. In recent times following ethnic conflicts where older societies broke up and what was called ethnic cleansing occurred (as in the former Yugoslavia), or where there were violent ethnic conflicts within nations and cities (such conflicts were almost universal) multiculturalism was seen in a very much more negative light. In the United Kingdom for example when there were disturbances involving violent conflict between Asians and native British citizens, such conflicts were diagnosed as due to multiculturalism. Economic migrants or political migrants and refugees were seen as endangering the unity of society and this unity was seen as having to be defended against multiculturalism.

\section{Philosophical and Social Science Views of Multiculturalism}

5. During the past 25 years multiculturalism was also debated amongst philosophers and social scientists.

6. In political philosophy the question arose in attempts to define the nature of a good liberal society. Such a society, it had been thought, would involve the guarantee of the rights of individuals. (See for instance. Walzer and Miller 1995), but now the question was asked whether such rights should be extended to groups. Prima facie it appeared that the very recognition of groups would involve a denial of individual rights. Charles Taylor, however, saw what he called recognition as essential to the concept of rights, and individuals could be recognised as members of groups (Taylor 1994). Kymlicka raised similar issues in writing about multicultural citizenship (Kymlicka 1995). Both of these writers being Canadian had to deal with the special problem of Quebec's claims to a separate political identity at the same time as discussing the identity of dispersed groups of immigrants and their descendants. A related question arose in Europe where Baubock posited the idea of a transnational citizenship alongside that of national citizenship (Baubock 1992).

7. All of these approaches implicitly involved a positive evaluation of multiculturalism. So too does that of the British Indian political philosopher, Bhiku Parekh (Parekh 2000). Parekh raises the question of the possibility of culturally distinct groups co-existing in a single society. He believes that they can, and that the multicultural nature of such a society should be welcomed and celebrated. Societies with single unitary cultures for him are no longer likely in the modern world as a result of migration. Far more likely are societies in which multiple cultures coexist and it is important for him that they should all have equal respect. Parekh coupled this theoretical work with his leadership of a Commission for a Multiracial Britain which sought to spell out the policies and institutions necessary to create a society in which racial discrimination, exploitation, and oppression ${ }^{1}$ were prevented. (Runnymede Trust 2000) 


\section{An Alternative Theory of Multiculturalism}

8. Barry (1999) has offered a sharp critique of the theories on multiculturalism discussed above. He sets out to defend the values of a liberal society which he believes is opposed to what is advocated in these theories. He believes that they are wrong in seeing the various groups which they discussed as only culturally different and wishes to insist upon their political relations. When they are thus understood they present the real problem to which liberal political theory has to address itself.

9. In discussing Barry's work (Rex 2001) I have argued that there is a limited version of multiculturalism which can be sustained even if his basic criticism is accepted. I base this on the Marshall's theory of citizenship (Marshall 1951) and a British definition of the term integration as it should appropriately be applied to immigrant ethnic minorities (See Rex and Tomlinson 1979).

\section{3 (i). Social Citizenship and the Welfare State}

10. Marshall's problem is not directly concerned with immigrant ethnic minorities. Rather it seeks to show how class loyalties and class conflict have come to be transcended by the concept of citizenship. The first stage of this transcendence is in the legal sphere in which all individuals regardless of class have equality before the law. The second is political. When a universal franchise is achieved all individuals share in controlling the government. The third, gradually being achieved in the post 1945 world, is social. This involves: insurance which provides a minimum income in times of unemployment and ill health, free collective bargaining on the part of workers in dealing with employers over wages and conditions of work; minimum standards of housing, education; and health care free to all at the point of delivery. These ideas of Marshall were based upon the work of Beveridge as set out in his book Full Employment in a Free Society (Beveridge 1944) and in the Report on Social Insurance and Allied Services (Beveridge 1942). Together Beveridge and Marshall laid the foundation of what came to be called the Welfare State. $^{2}$

11. For my own part I expressed some doubt as to whether citizenship would totally and permanently transcend class (Rex 1961). I argued that it would so long as there was a balance of class forces, but that, if this balance was destroyed, class conflict might well be resumed. This was an important issue in Britain during the period of the Labour government of 1964 and later during Conservative administrations between 1979 and 1993. The Labour government had issued a White Paper entitled In Place of Strife, (Department of Labour and Productivity 1969) which envisaged co-operation between trades unions and employers organisations in government sponsored institutions. The Conservative government of the eighties subsequently

1. There are of course important reasons for rejecting the use of the term racial in this context but in documents addressed to a wider popular or political audience terms like ethnic and racial are often used interchangeably. It would be entirely wrong however to accuse Parekh or his colleagues of not understanding the dangers of what may be called biological racism. (For a discussion of that question see Montagu's Statement on Race in which he sets out the findings of four UNESCO statements on this question. (Montagu 1972).

2. Of course there are a number of alternative types of Welfare State as Esping Anderson has shown (Esping-Andersen 1990), but the British version is one which has been widely influential. 
greatly weakened workers rights and envisaged a much more limited Welfare State which involved little more than social insurance and a free health service. Nonetheless a later Conservative government declared itself in favour of a classless society.

12. What has been discussed here is the evolution of social policy and political institutions in Britain, but very similar ideas were operative in most West European countries. Radtke (1994), for instance, speaks of the social democratic welfare state in which a plurality of conflicting interest had lead to a compromise after negotiation.

13. All of the above discussion refers to the possibility of class conflict and class compromise. None of it refers to the position of ethnic groups which are the centre of discussions about multicultural societies. To this question we must now turn.

\section{3 (ii). The Integration of Immigrant Ethnic Minorities}

14. There have been three basic European responses to the arrival of immigrant ethnic minorities in the post 1945 period. The first is that of assimilationism which is most strongly affirmed in France. The second is that of the gastarbeider system of the German speaking countries under which immigrant workers are denied political citizenship. The third is one or other sort of multiculturalism commonly thought to be exemplified by Sweden, the Netherlands and the United Kingdom.

15. In the Swedish case provision for ethnic minorities was conceived as part of the provision of the Welfare State. The problem which the Swedish government faced however was that of who was to be chosen to represent the immigrant minorities. They were accused of choosing traditional leaders, usually elderly men. Their critics such as Schierup and Alund (1990) argued that in fact younger members of these communities were not represented. They also argued that, in any case they tended to form cross ethnic alliances and alliances with dissident Swedish youth creating new syncretic cultures.

16. The historic Dutch response to cultural diversity had been what came to be called pillarisation. This was the establishment of separate educational systems, separate trades unions and separate media for Catholics, and Protestants. This policy was extended to deal with ethnic minorities. One important critic of this policy, Jan Rath (1991) suggested, however, that the policy of minorisation by no means necessarily implied that minorities would be subject to equal treatment. As he saw it minorisation could mean the singling out of those called minorities for unequal treatment.

17. In the United Kingdom after a brief acceptance of a policy of assimilation in education in 1964, the government accepted the notion of integration. This was defined by the Home Secretary, Roy Jenkins as "not a flattening process of uniformity but cultural diversity, coupled with equal opportunity in an atmosphere of mutual tolerance"(Rex and Tomlinson 1979).

18. What is significant about this definition is that it dissociates itself from any form of multiculturalism which would permit the unequal treatment of minorities. In fact it relates the notion of integration to Marshall's notion of social citizenship.

19. I have suggested that the Jenkins definition also suggests the existence of two cultural or institutional domains. On the one hand there is a public political culture centred around the idea of a welfare state in which all have a minimal degree of equality. On the other there are the 
separate cultures of the different ethnic communities including the host community. These separate cultures involve the members of each community speaking their own language amongst themselves, practising their own religion and having their own family practices.

20. This, however, is only a general starting point for the definition of an egalitarian multicultural society. In practice it raises many difficult questions and is contested by a number of different groups.

21. A first question is that of why separate communal cultures should continue to exist. There are three elements involved in answering this. The first is that they are allowed to exist in the belief that they may have value in themselves. Accepting this is implied by the notion of mutual tolerance. The second is that it provides individuals with a moral and emotional home which is essential for their personal psychological stability. Durkheim in his classical work, The Division of Labour (1933) had argued that such stability was only possible under conditions of organic solidarity if there was some grouping between the individual family and the state. He thought that this might be achieved through the development of occupational guilds. This is obviously unlikely in modern times but clearly ethnic minority groups can perform a similar role. This is true also for the members of the host society. Quite apart from their participation in the public political institutions of the welfare state they too have their culture and organisations in which they feel at home. The third reason for preserving these groups is that they make possible collective action to protect their members in political life.

\section{3 (iii). Problems of the Two Domains thesis}

22. Everything said so far provides only a starting point for the analysis of multiculturalism. We must now consider some of the problems in the two domain thesis. These include: problems within the educational system; the attempt to extend the values of the public political culture into the private communal sphere and, per contra, the claim that the values of the private communal cultures should be extended into to the public realm; and, finally the different problem of the degree of commitment or lack of commitment of immigrant groups to living in a host society.

\section{3 (iii) a. The Problem of Multicultural Education}

23. The one institution which clearly straddles both the private and public spheres is that of the educational system. Here we can distinguish with some oversimplification between primary and secondary schools.

24. Primary schools have amongst their functions one which they share with families. Unsocialised babies are the barbarian invaders of the social system. They have to learn and accept a complex set of norms if they are to become full social beings. These their parents teach them and so do their primary schools. In the primary schools they also become bilingual. Ideally they start to learn in their home language but they also have to learn the language of the host society and for school purposes to use it as their main language.

25. In secondary education students may be seen as being prepared for entering a wider world governed by norms of a different kind. These norms involve individualism and competition even though these may be contained within some conception of common citizenship. They are being prepared for the world of work and as well as learning relevant norms they must acquire skills. ${ }^{3}$ 
26. One should now ask whether there is any place within schools for the perpetuation of different languages and cultures.

27. One view which has considerable currency in many countries is that the perpetuation of these languages in schools increases students' self-esteem and enhances their performance. This view was robustly criticised by a West Indian schoolteacher, Maureen Stone, in England. She argued that the relation between low self esteem and poor performance had never been proved She therefore believed that any supplementary education should be devoted to basic skills and not to education in different cultures (Stone 1985). In saying this she was recognising that schools are concerned with the wider world and participation in the public realm. Another author, Jennifer Williams, pointed out that where multicultural education was taught in schools it was taught in the low status uncertificated parts of the syllabus. Despite these criticisms or taking account of them there have been some attempts in Britain to foster the study of minority languages and cultures in the high status certificated parts of the syllabus. (Williams 1967). Those who support such developments clearly have in mind the creation of a multicultural society in which a variety of cultural traditions are respected.

\section{3 (iii) b. The Public and Private Domains Reconsidered}

28. The sharp distinction between public and private domains which was our starting point is disputed from both sides. It is disputed by some who believe that there are certain values in the public sphere which apply also in the private and some who believe that private communal value also apply in the public domain. It is also the case that some immigrant ethnic communities may be transnational in character and have commitments elsewhere.

29. Those who argue for extending the values of the public domain into the private sphere often do so in the name of human rights. This is a notion which includes more than the commitment to the values of the Welfare State and suggests that our definition of the public sphere must itself be revised. This is particularly true of feminist claims. Host society feminists usually claim that the private family practices of immigrant communities are unacceptable. They suggest that women these communities are oppressed by their menfolk and that they involve arranged and forced marriages. To this those who speak for immigrant communities may reply on each point. They point out that the oppression of women is the product not of their culture as such but of the village practices which they bring with them. These they agree should be altered and they are prepared to join in altering them. Further they say that what they are doing is protecting their women and children from a society which is sexually promiscuous and whose symbols are the pornographic magazine and the sex shop. This could be, and sometimes is, a basis for dialogue with more sophisticated host society feminists who may recognise these problems from a feminist point of view. So far as arranged marriages are concerned they would argue that these need not and should not be forced and that the normal random mating practices of Western Europe are not necessarily preferable to arrangements in which the family of a bride frequently ensure that she is supported with a significant dowry. In modern conditions this

3. Secondary schools clearly also prepare their students for a socially stratified world and they themselves may be stratified. In England there has been prolonged debate about whether there should be a tripartite system of schools or whether all children should study in the same comprehensive schools. Similar arguments occur in other European countries although they may be resolved in different ways there. 
might involve a contribution to the cost of a house or a motor car. The notion of being in love which Westerners claim is essential to marriage is something which may be longer and more lasting in arranged marriages than it commonly is in the West.

30. The opposite objection to the notion of two domains comes from immigrant communities. Some would say that their culture is not simply for the private sphere This is what many Muslims are claiming when they say that Islam is a whole way of life. Thus they would see the values of the Welfare State or those advocated in the name of human rights are integral to their own beliefs. If this is so then we cannot simply regard the political culture of the public domain as secular. It may be shared between different communities.

31. The real revision of the two domain thesis which is required is that it should leave open a space for dialogue.

32. In estimating the possibilities of integration of minority communities we should also avoid the essentialist view that the cultures which we are seeking to integrate are unchanging and rigid. In fact I have suggested they have three points of reference. The first is to a homeland which is itself undergoing change; the second is to the land of present settlement; and the third to possible countries of onward migration. This raises the whole problem of the nature of transnational migrant communities which I have discussed elsewhere (Rex 1996). So far as their position in the land of first migrant settlement is concerned immigrant communities may well have a modernising perspective since it is in their interest to fight for equality and equal treatment, even while being bound together by the use of their mother tongue amongst themselves and dealing with the life crises of birth marriage and death in their own religious ceremonies. In addition to all these factors some of the second third and later generations in immigrant families may well defect from their communities and culture and become assimilated. All of these factors suggest that the problem of integrating immigrant communities may be a more temporary and simple one than many of the advocates and opponents of multiculturalism believe.

33. We have already seen that the culture and institutions of the public domain consist of more than those related to equality in the Welfare State. They include concepts of human rights as we have seen but they also include all that is involved in participating in a modern economy and polity and accepting its

34. Criminal and civil law. ${ }^{4}$ This is something which immigrants accept because it is essential to the migrant enterprise.

35. Next under this head dealing within the difficulties of the two domains thesis there is the question of whether there are not some new emergent shared areas of life. The most obvious of these concern cuisine. It is often remarked in Britain that Chicken Tikka Masala is the most purchased packed meal in supermarkets and it is true in all modern societies that there does develop a shared interest in a new range of dishes of international origin. The other rather different shared area concerns literature in particular but probably most of the creative arts. The

4. There are of course minorities especially in Muslim communities who would support schools preparing their students for living in a separate society and there are even those who would wish to find ways of applying Sharia law in domestic matters. It is to be doubted, however, whether even those who live in communities with these aims do not also adjust to living in a modern economy and polity for most of their lives 
most important literature reviewed in prestigious magazines deals with many immigrant and multi-cultural problems while music also obviously crosses borders. Obviously there is a case for allowing for a domain of shared culture between those we have discussed but this does not necessarily mean that the two separate domains which we have discussed do not exist or that shared cuisine and shared creative arts necessarily foreshadow a shared new culture overall.

36. Finally we should notice that this emergence of some shared intermediate institutions in particular societies goes along with a process of the globalisation of culture at least among elites.

37. We have so far considered the various forms of multiculturalism in European societies particularly in the Netherlands, Sweden and the United Kingdom. To complete the picture, however, it is necessary to consider the cases of the old British Commonwealth countries of Australia and Canada which although first settled by British and British and French settlers sought to develop multicultural policies which would indicate the position of various later grous of settlers as well as the aboriginal or native people.

\section{Sub-national Societies and the possibility of devolution}

\section{4 (i) a. Sub-Nationalisms and the Process of Peaceful Devolution}

38. Arguments about multiculturalism usually confuse the problems which we have been discussing - those of the integration of immigrants - with problems of a different kind. These are those of the place of sub-national units such as the Welsh, Scots and Irish in Britain or the Catalans and Basques in Spain. Separately from these cases are those of bi-national states such as Belgium and Canada. In each of these cases the claims of nationality may be based upon linguistic, religious or cultural unity or they may simply be based upon residence in the region of the sub nation. Catalonian nationality is attributed to all those who live in the sub-national area and Scottish nationality and the right to vote for a Scottish Parliament is attributed to all those who live in Scotland. Slightly different situations occur in Belgium and France. In Belgium Walloonia is French speaking and Flanders Flemish or Dutch speaking, while Brussels is bilingual. Government at a national level is shared by the two groups, but is in the hands of the French speaking in Walloonia and the Flemish/Dutch speaking in Flanders. In Canada the claims of nationalism are made on behalf of Quebec led by a French speaking majority and not on behalf of other Francophones in Manitoba and other provinces.

39. Devolution may involve the concession of more or less powers to the sub-nations. The greatest degree of devolution in the United Kingdom is accorded to Scotland with its Scottish Parliament, while the Welsh Assembly has far more limited powers. The situation in Catalonia is similar to that of Scotland but in both these cases the sub-national government is subordinate to that in Madrid or London. In both cases and in those cases where devolution is more restricted there are minority parties aiming at secession. (For a discussion of these cases see Guibernau and Rex 1997)

40. Similar problems are to be found in other parts of the existing European Union. France, for instance, has a problem of devolution in Corsica. Italy has such a problem both in dealing with its regions and with its island dependencies in Sicily and Sardinia. Greece has a problem with its island dependencies in Corfu and Crete and on its northern border with Macedonia and Thrace. 
41. Again there are problems of devolution in the countries envisaged as the first entrants to an enlarged European community some of whom also have border problems. This is true of the Czech Republic, Slovakia and Hungary all of which have had to deal with the question of devolution, and it is even more true of the countries who might be later entrants such as Romania and Bulgaria. Among those selected for earlier entry moreover there are some like the Baltic Republics and Cyprus which have very special difficulties. In the case of the Baltic Republics there are large Russian minorities who were previously ruling minorities, while in the case of Cyprus the recognised Greek Cypriot territory will be required to have negotiated at least a loose federation with the unrecognised Turkish part of the island

\section{4 (i) b. The problem of incorporation into supranational units}

42. A new situation arises with the emergence of supra-national units like the European Union because it raises the possibility of the regions dealing with the supra-national government directly, True, ultimate power in the EU lies with the Council of Ministers drawn from the central governments of nation states, but there are many forms of development in which the EU deals directly with the regions. This raises the possibility that radical groups in the sub-national units may not simply seek secession from their own nation states but may seek to turn the EU into a Union of regions rather than of nation states.

43. The problem of devolution was also dealt with in the former Soviet Union. Although the Communist Party controlled the whole society, Stalin's policy allowed varying degrees of autonomy within particular departments in different kinds of autonomous regions (Connor, Walker 1994). Tartarstan represented a case in which a very workable type of co-operation was worked out between the regional and central Soviet government. (Yemelianova 1999) As in the West, however, there were a variety of political and religious groups who sought more independence and some of them had international connections outside the Soviet Union.

\section{4 (ii). Cases of Armed Ethnic Conflict}

44. In the cases so far discussed we have been assuming that some degree of peaceful devolution is possible and that there will be very few extremists seeking to bring about change by violent means. This however has not been the case with the Basques in Spain or the Republicans in Northern Ireland. There political parties have emerged which engage in violent armed struggle participants within which are seen as terrorists by the central governments of Spain and the United Kingdom. There is something in common between these two cases and it is not surprising that there have been contacts between the Basque separatist organisation ETA. and the Provisional IRA. Nonetheless there are differences between the two cases. In the case of Spain the conflict is between one ethnic group and the Spanish state. In the case of Northern Ireland there are two ethnic groups in conflict with one another, one seeking ultimate unification of Northern Ireland and the Irish Republic, the other professing loyalty to, and demanding continuing union with, a United Kingdom.

45. What the two groups have in common is their use of violence. In both cases moreover there is a problem of their relationship with parties who share their aims but oppose the use of violence. This is a complex relationship in which the moderate parties give some protection to the more radical and violent ones. 
46. In the case of Spain the response of the government has been to take strong measures against violence but also to offer some degree of devolution. In the Northern Irish case the British government has had to use its own army to oppose two groups of paramilitaries, even though one fights in the name of loyalism, and the British army is often accused of devoting its energies to fighting the Republicans. In this case there is also an offer of ultimate devolution but this has to follow a delicately and carefully constructed Peace Process.

\section{4 (iii). Armed Conflict in Post-Communist Societies}

47. The overall title of this article refers to Multiculturalism and Political Integration in Modern Nation States. Thus far, however we have referred to only one type of modern nation state namely that based upon private economic enterprise or a mixture of private and public enterprise, parliamentary democracy, and a tendency to move towards some kind of welfare state. The other type of modern nation state is that based on Communism. As we have seen such states as dealt with the potentiality of ethnic conflict relatively successfully until Communism as an economic and social system began to collapse in 1989. At this point many groups sought secession from the state and engaged in violent conflict with the successor states and with one another.

48. The experience of the former Yugoslavia in this respect has been central to the study of ethnic conflict and the prospects of multiculturalism. Under Tito Serbs, Croats, Bosnians, Montenegrians, Herzegovinians, Slovenians and Macedonians were held together by national Communist government albeit through a subtle balancing of ethnic forces at local level. With the collapse of Communism, however, ethnic groups separated themselves from one another and there were brutal wars between them and ethnic cleansing within each one of them. The Bosnian and Kosovan wars led to outside intervention by the international community which then sought to promote new constitutions based upon some notion of multicultural balance. These new constitutions depended on outside force but the outside powers aimed at being able to withdraw. It was easy enough to suggest new multicultural constitutions but harder to realise them in practice. The various ethnic groups who were required to implement the new constitutions entered into discussion with their smoking guns still on the conference table. Some of the problems involved were made explicit in The Kosovo Report (Independent International Commission on Kosovo 2000) which recommended independence for Kosovo on condition that it became fully multicultural.

49. Less well known are the problems which faced successively the Soviet Union, the Commonwealth of Independent States and the remaining Russian Federation. There the various ethnic political and religious groups which had always resisted central government were now able to pursue secessionist liberation struggles and were inevitably dubbed as terrorists by the central governments involved. The war in Chechnya is the best known of these conflicts but there were many others in the Caucasus, in Georgia, Azerbaijan and Armenia and in the former Central Asian territories involving complex alliances between religious sects and political parties, coupled with intervention from allies in neighbouring states. (Yemenialova 2001). 


\section{The Prospects of Multiculturalism after the American led War against terrorism}

50. After the attacks on New York and Washington in September 2001 a new political climate emerged which was fearful of multiculturalism. The diversity of cultures appeared as providing a base for more terrorist attacks and Islam particularly was seen as doing this. An attempt was made by the United States to establish a coalition of nations against terrorism. Which would destroy terrorist bases across the world. On the other hand there was little chance of those opposing this coalition seeking a multicultural solution. Rather they established their own international networks of opposition and regarded any party, sect, or nation not joining these networks as allies of the United States led coalition. The war against terrorism continued in 2002 making multiculturalism and impossible and unrealisable ideal except in the limited sense in which the coalition or the international network of resistance used it to strengthen its own unity.

51. Within this framework the United Kingdom's commitment to multiculturalism was weakened when it faced more local but violent conflicts between White natives and Asians in some Northern cities and between local people and asylum seekers in Glasgow and other places. At the beginning of the year 2002 there was considerable confused debate amongst politicians and the press about the dangers of multiculturalism which was identified with segregated forms of housing and education. There was a new emphasis upon the importance of immigrants and their children learning English as rapidly as possible and learning about the duties of a unitary British citizenship. Thus whereas the United Kingdom had been a place where multiculturalism could be sympathetically discussed and shown to be compatible with a modern society and a welfare state it was now seen as a danger. The predominant view now was one which was far more like the assimilationist French approach. In this new climate any residual multiculturalism will have to be shown to be compatible with an essentially unitary society. The sort of multiculturalism which has been defended in this article if, of course, compatible but even such a policy outline will find that it is difficult for it to get a hearing.

\section{Conclusion}

52. This article has ranged widely over a number of topics including nationalism and devolution in West Europe, South East Europe and the countries of the former Soviet Union at the same time as dealing with the settlement of immigrant minorities who do not make the claims which sub-nationalities do. It has been necessary to do this because that is how the issue appears in public debate, whether that debate is sympathetic or hostile to the multiculturalist idea. Throughout moreover the article has recognised that national and immigrant minorities cannot be simply the objects of policy thought out and imposed from above. A viable multicultural policy will be one which recognises conflicts of ideas and interests between different groups and considers the way in which such conflict can lead to negotiation and compromise.

\section{References}

Barry. B., 1999,Culture and Equality: An Egalitarian Critique of Multiculturalism, Polity Press, Cambridge.

Beveridge, W., 1942, Social Insurance and Allied Services, HMSO, London 
Beveridge, W., 1944, Full Employment in a Free Society, G Allen, London.

Baubock, R., 1992, Transnational Citizenship, Edward Elgar, Aldershot.

Connor, Walker, 1994, Ethnonationalism: The Quest for Understanding. Princeton University Press, Princeton.

Department of Employment and Productivity, 1969, In Place of Strife: A Policy for Industrial Relations, HMSO, London, Cmnd 3888.

Durkheim, E., 1933, The Division of Labour, Free Press, Glencoe, Illinois.

Esping-Andersen, G., 1990, TheThree Worlds of Welfare Capitalism. Polity Press, Cambridge

Guibernau, M., and Rex, J., 1997, The Ethnicity Reader: Nationalism, Multiculturalism and Migration, Polity Press, Cambridge.

Independent International Commission on Kosovo, 2000, The Kosovo Report: conflict, international response, lessons learned. Oxford University Press, Oxford

Kymlicka, W., 1995, Multicultural Citizenship, Oxford University Press, Oxford.

Marshall, T., 1951, Citizenship and Social Class, Cambridge University Press, Cambridge.

Montagu, A., 1972, Statement on Race: An annotated elaboration and exposition of the four statements on race issued by the United Nations Educational, Scientific and Cultural Organisation, Third Edition, Oxford University Press, Oxford.

Parekh, B., 2000, Rethinking Multiculturalism: Cultural Diversity and Political Theory, Harvard University Press, Cambridge, Mass.

Radtke, F-O, 1994, "The Formation of Ethnic Minorities: The transformation of Social into Ethnic Conflicts in the So-called multicultural Society, The German Case" in Rex, J., and Drury, B., (Editors) Ethnic Mobilisation in a Multicultural Europe, Avebury Aldershot.

Rath, J., 1991, Minosering: De Social Constructe van Ethnische Minderheden, Ph.D. Thesis, University of Utrecht.

Rex , J., 1961 Key Problems in Sociological Theory, Routledge and Kegan Paul. London.

Rex, J., 1996. Ethnic Minorities in the Modern Nation State: Working Papers in the theory of Multiculturalism, MacMillan, Aldershot and St Martin's Press, New York.

Rex. J., 2001, Review of Barry B., Op.Cit. in Innovation in Social Science Vol 14, Number 3 , Abingdon.

Rex J., and Tomlinson S., 1979, Colonial Immigrants in a British City: A class Analysis, Routledge and Kegan Paul, London 
Runnymede Trust, 2000, The Future of Multi-ethnic Britain, The Parekh Report, Runnymede, London.

Schierup, C-U and Alund, A., 1990, Paradoxes of Multiculturalism. Avebury Aldershot.

Stone, M., 1985, The Education of the Black Child: TheMyth of Multicultural Education, Fontana Press, London.

Taylor, C., 1994, "Multiculturalism and The Politics of Recognition" in Guttman, A., (Editor) Multiculturalism: Examining the Politics of Recognition" Princeton University Press. Princeton.

Walzer, M., and Miller, D., 1995, Pluralism Justice and Democracy. Oxford University Press, Oxford,

Williams J., 1967, "The Young Generation" Chapter X in Rex, J., and Moore, R., Race Community and Conflict, Oxford University Press, Oxford.

Yemenialova, G., 1999, Islam and Nation Building in Tatarstan and Dagestan in the Russian Federation, Nationality Papers, Association for the Study of Nationalities, Vol 27 Number 4, London and 2001, Sufism and Politics in the North Caucasus. Nationality Papers, Association for the Study of Nationalities Vol 29 Number 4, New York. 